\title{
Jean-Claude SERGEANT, Les Médias britanniques
}

Paris: Ophrys-Ploton, 2004

\section{Martin Harrison}

\section{OpenEdition}

\section{Journals}

Electronic version

URL: http://journals.openedition.org/rfcb/3353

DOI: $10.4000 /$ rfcb.3353

ISSN: 2429-4373

Publisher

CRECIB - Centre de recherche et d'études en civilisation britannique

\section{Printed version}

Date of publication: 1 September 2004

ISBN: 2-911580-19-2

ISSN: 0248-9015

\section{Electronic reference}

Martin Harrison, « Jean-Claude SERGEANT, Les Médias britanniques », Revue Française de Civilisation Britannique [Online], XIII-1 | 2004, Online since 01 September 2004, connection on 25 September 2020. URL : http://journals.openedition.org/rfcb/3353 ; DOI : https://doi.org/10.4000/rfcb.3353

This text was automatically generated on 25 September 2020

\section{(c) (i) (9)}

Revue française de civilisation britannique est mis à disposition selon les termes de la licence Creative Commons Attribution - Pas d'Utilisation Commerciale - Pas de Modification 4.0 International. 


\title{
Jean-Claude SERGEANT, Les Médias britanniques
}

Paris: Ophrys-Ploton, 2004

\author{
Martin Harrison
}

\section{REFERENCES}

Jean-Claude SERGEANT, Les Médias britanniques, Paris: Ophrys-Ploton, 2004, 352 p. Pbk:

17,50 €. ISBN 2-84120-104-X, 2-7080-1006-9.

1 Recent years have brought a steady stream of work on the media in Britain, some thoughtful, some polemical, some simply anecdotal but collectively contributing to an impression that the media have an increasingly important social role. Several 'serious' newspapers regularly give more space to developments in the media than to reporting parliament. Is that an accurate reflection of the realities of power in Britain or a sign of an industry imbued with an excess of self-importance?

2 Much airing of such issues within Britain is highly anglocentric. Not the least merit of Jean-Claude Sergeant's study is that he brings to it an expert but dispassionate external eye. This is a sober, scholarly view of the evolution of the media since World War II, covering broadcasting, the press and, to a lesser extent, magazines. The latter are inescapably dispatched briefly. A full assessment would have to encompass not only the likes of The Economist, Cosmopolitan, FHM and Hello!, which Sergeant discusses, but also the ethnic press and specialist journals such as Housing Today or the Farmer's Weekly, which achieve 'mass' circulation and influence within their chosen fields. His summary treatment of the internet is less excusable: the 'reach' of the BBC web site is now enormous, while the Guardian has reported that in a recent month some nine million different users accessed over one hundred million Guardian Unlimited pages. The reports of the Hutton enquiry and the Butler review reached a vastly greater readership online than they would have done if they had been published solely in traditional form. Doubtless Sergeant will have more to say on such developments in subsequent editions. 
That reservation apart, he leads the reader carefully but confidently and in some detail through enormous changes, some structural or technological, others financial, legal or regulatory. In 1945, newspapers were anorexic, monochrome and printed by hot-metal techniques by a workforce entrenched in its arcane and costly 'Spanish practices'. Today, the old 'Fleet Street' is dispersed, militant unionism vanquished and fatter newspapers, using colour, are printed in modern plants. Broadcasting has expanded from a handful of $B B C$ radio networks through the advent of television and the breaking of the monopoly to a multiplicity of radio and television channels and delivery platforms, unimaginable in 1945 by any but visionary science fiction writers. Sergeant takes the account right up to Lord Hutton's report and the struggle for the Telegraph titles. He is invariably lucid, perceptive, judicious and fair-minded; he even sees there is something to be said for John Birt and Rupert Murdoch.

But Sergeant shows that this is not a simple story of the rise and rise of the media. He is informed and alert on issues like regulation, freedom of information, the emerging right to privacy and the power of big (and mainly foreign) corporations like News International. He also explores the fragile and darker side of the media landscape. The number of newspapers may hold remarkably stable but, both nationally and locally, circulations are in long-term decline, with younger people particularly less inclined to read any paper regularly; nobody seems capable of turning the tide. Television's reach is well nigh universal but audiences are increasingly fragmented. This has greater implications for the licence fee (if not necessarily this time round) than any fallout from the BBC's battles with the government, while also making the ITV more vulnerable. Insecurity and intense competition inevitably affect quality. The popular tabloids have become more narrowly focussed than ever on crime, the couplings of soap opera stars and strident campaigns against asylum seekers or pedophiles. Even weighty papers pay more attention to lurid criminal cases and minor celebrities than a few years ago. The main TV channels have all but banished current affairs from peak hours in place of soap operas and 'makeover' or 'reality' shows.

5 British newspapers are consummately professional products. Yet public distrust, especially of the 'redtops' or 'comics' has, if anything, deepened. Despite that, on issues ranging from immigration to the MMR vaccine and the European constitution, they unquestionably influence the public agenda and governments ignore their campaigns at their peril. But they are by no means omnipotent. In a highly competitive market content is shaped by producers' assessment of what people will buy or watch (which admittedly they have helped to mould in the first place). The outcome is Big Brother rather than Panorama or kiss-and-tell rather than global warming. When the press does tackle politics, even quality papers have a tendency to lace reportage with opinion or affect a sceptical cynicism as corrosive as the linguistic overkill of their downmarket counterparts. Happily, radio and television still strive to be balanced and fair - though voices can now be heard pressing for the sort of partisan coverage on the lines of Fox News. For better and worse, Britain may be getting the media it deserves. Alas, many might say. Yet Sergeant's final assessment is relatively benign. (About the only point where he is waspish is in dealing with an English journalist's patronising dismissal of the French media.) Recognizing undoubted strengths, while aware of excesses and vulnerabilities, he concludes with the hope that the media will continue to be "les soutiens d'une démocratie où dynamisme, créativité et respect de la liberté de chacun font bon ménage ». One must hope his optimism is warranted. 


\section{AUTHORS}

MARTIN HARRISON

Université de Keele 